\title{
Vanskelige spørsmål i folkeretten
}

\author{
Av stipendiat Sondre Torp Helmersen
}

I denne artikkelen drøftes folkerettslige spørsmål som kan være vanskelige å besvare, basert på forfatterens erfaringer som kurslærer i folkerett. Syv spørsmål behandles: statsansvarets «objektive» karakter, mottiltak mot tredjestater, jus cogens kontra erga omnes, vilkårene for statsdannelse, begrensninger i sikkerhetsrådet kompetanse, skillet mellom intervensjon, bruk av væpnet makt og væpnet angrep, og retten til uskyldig gjennomfart til havn.

Sondre Torp Helmersen (f. 1987) er Master i rettsvitenskap fra Universitetet i Oslo (2011) og LL.M. fra Cambridge (2014). For tiden er han stipendiat ved Institutt for offentlig rett, Universitetet i Oslo, hvor han skriver ph.d.-avhandling om juridisk litteraturs stilling i folkeretten. Helmersen har vært kurslærer i folkerett siden 2012, og har tidligere jobbet i Utenriksdepartementets rettsavdeling. Han er forfatter av boken Folkerett $i$ et nøtteskall (Gyldendal 2014).

\section{Innledning ${ }^{1}$}

Å ha vært kurslærer i folkerett i noen år, har gitt meg et inntrykk av hvilke faglige spørsmål studenter pleier å streve mest med. I denne artikkelen tar jeg opp noen spørsmål som pleier å gå igjen, og som jeg også mener er viktige for studenter å kunne besvare - som eksamenskandidater og eventuelt som fremtidige folkerettsjurister. Jeg tar opp syv ulike spørsmål i hvert sitt punkt nedenfor:

- At statsansvar kan sies å være «objektivt», det vil si utløst uten skyld, men at den enkelte folkerettsregel kan kreve skyld ${ }^{2}$

- At det er tvilsomt om ikke-fornærmede stater (tredjestater) kan iverksette mottiltak, og at dette i så fall bare er aktuelt for erga omnes-forpliktelser og kollektive traktater ${ }^{3}$

- Forskjellene mellom jus cogens og erga omnes ${ }^{4}$

- De ulike vilkårene for statsdannelse, og hvordan de kan deles opp og klassifiseres ${ }^{5}$

- At FNs sikkerhetsråds materielle kompetanse er begrenset, selv om disse grensene er vanskelige å håndheve ${ }^{6}$

- Forskjellene mellom intervensjon, bruk av væpnet makt, og væpnet angrep ${ }^{7}$

- At reglene om uskyldig gjennomfart gjelder for et skip som seiler til havn, men bare for skip som har tillatelse til dette fra kyststaten ${ }^{8}$

\footnotetext{
${ }^{1}$ Takk til Sofie A. E. Høgestøl og Stian Øby Johansen for nyttige innspill til artikkelen.

2 Dette er behandlet i Morten Ruud og Geir Ulfstein, Innføring i folkerett, 4. utgave Oslo 2011 s. 302-303 og 305-306, Carl August Fleischer, Folkerett, 8. utgave Oslo 2005 s. 201, og Sondre Torp Helmersen, Folkerett $i$ et nøtteskall, Oslo 2014 s. 132 og 136.

${ }^{3}$ Dette er behandlet i Ruud og Ulfstein, op.cit., s. 310 og Helmersen, op.cit., s. 150-151.

${ }^{4}$ Dette er behandlet i Ruud og Ulfstein, op.cit., s. 68 og 307 og Helmersen, op.cit., s. 46-49.

${ }^{5}$ Dette er behandlet i Ruud og Ulfstein, op.cit., s. 114-120, Fleischer, op.cit., s. 67-68 og Helmersen, op.cit., s. $62-66$.

${ }^{6}$ Dette er behandlet i Ruud og Ulfstein, op.cit., s. 213-218, Fleischer, op.cit., s. 318-320 og Sondre Torp Helmersen, op.cit., s. 117 og 162-163.

${ }^{7}$ Dette er behandlet i Ruud og Ulfstein, op.cit., s. 190-201, Fleischer, op.cit., s. 91-93, 234-235 og 295-296 og Helmersen, op.cit., s. 112-115 og 123.

${ }^{8}$ Dette er behandlet i Ruud og Ulfstein, op.cit., s. 148-149, Fleischer, op.cit., s. s. 118-119 og Helmersen, op.cit., s. 93.
} 
Spørsmålene diskuteres med utgangspunkt i folkerettens rettskilder. Disse er det generelt viktig å ha god kontroll på for å kunne løse folkerettslige spørsmål. En fellesnevner for spørsmålene er dessuten at de skrevne rettskildene ikke forteller den fulle historien. Da er god kildebruk ekstra viktig. De viktigste kildene er traktater og sedvanerett.

På eksamen har man med seg en traktatsamling, og man bør vite hvor man finner sentrale traktater, som FN-pakten, ICJ-statuttene, Wien-konvensjonen om traktatretten (VCLT), Wien-konvensjonen om diplomatisk samkvem (VCDR), Havrettskonvensjonen (UNCLOS), SP og ØSK, Roma-statuttene, Montevideo-konvensjonen, EMK og Folkemordkonvensjonen.

Når det gjelder sedvanerett, er det mulig å utlede innholdet i denne fra traktater som reflekterer sedvanerett og fra rettspraksis. FN-pakten artikkel 2(4), 2(7) og 51, VCLT, VCDR, UNCLOS, ICJ-statuttene artikkel 38 og mesteparten av Montevideo-konvensjonen gir alle uttrykk for sedvanerett. Det samme kan antas om United Nations Convention on Jurisdictional Immunities of States and Their Property (som ikke har trådt i kraft), og Folkerettskommisjonens (ILCs) ikke-bindende artikler om statsansvar (RSIWA) ${ }^{9}$. Dessuten inneholder mange ICJ-avgjørelser uttalelser om hva som er sedvanerett, og man kan anta at disse er korrekte. ICJ avsier dommer, tar andre avgjørelser, og gir rådgivende uttalelser. Rådgivende uttalelser er i utgangspunktet ikke rettslig bindende. I realiteten har ICJs rådgivende uttalelser likevel omtrent tilsvarende rettskildevekt som dommer og andre bindende avgjørelser.

\section{Statsansvar er «objektivt» (men en regel kan være «subjektiv»)}

Staters ansvar for brudd på folkeretten reguleres av folkerettslig sedvanerett. Denne antas å være reflektert i Folkerettskommisjonens (ILCs) ikke-bindende artikler om statsansvar (RSIWA). Utkastet inneholder regler om hva som utgjør et folkerettsbrudd, og om konsekvensene av folkerettsbrudd. Noen konsekvenser utløses automatisk, som reparasjon (Artikkel 31). Andre konsekvenser utløses bare hvis en fornærmet stat (eller eventuelt en tredjestat, se punkt 4 nedenfor) ønsker det, slik som mottiltak og søksmål for en domstol. Temaet for dette punktet er de konsekvensene som utløses automatisk.

I norsk erstatningsrett skiller man mellom subjektivt og objektivt ansvar. Subjektivt erstatningsansvar utløses bare dersom den ansvarlige personen har utvist skyld. Objektivt ansvar utløses uavhengig av skyld hos den ansvarlige personen.

I folkeretten finnes det ikke noe generelt krav om skyld for å utløse de automatiske konsekvensene. Disse konsekvensene utløses alltid når det foreligger folkerettsbrudd, uten ytterligere vilkår. Denne delen av statsansvaret kan derfor sies å være «objektiv». Man skal altså ikke drøfte skyldspørsmål dersom man allerede har kommet til at det foreligger et folkerettsbrudd.

Man kan i denne forbindelse skille mellom primærregler og sekundæerregler. I folkeretten brukes disse begrepene gjerne om henholdsvis regler som inneholder rettigheter og plikter (primærregler), og regler som sier hva som skjer hvis disse primærreglene brytes (sekundærregler). For eksempel inneholder RSIWA sekundærregler, mens forbudet mot bruk

\footnotetext{
${ }^{9}$ Full tittel: «Responsibility of States for Internationally Wrongful Acts». Artiklene med kommentarer finnes i Yearbook of the International Law Commission, 2001, vol. II (Part Two) og vedlagt FNs generalforsamlings resolusjon 56/83 (12. desember 2001).
} 
av makt og reglene om diplomatisk immunitet er eksempler på primærregler. Skillet kan illustreres av Barcelona Traction-saken mellom Belgia og Spania. ${ }^{10}$ På primærregelnivået handlet saken om hvorvidt Spania hadde overholdt diverse folkerettsforpliktelser om hvordan selskaper skal behandles. Det ICJ først måtte avgjøre var imidlertid hvorvidt Belgia kunne gå til sak om dette. Dette reguleres av sekundærregler, som sa at Belgia ikke kunne til sak, til tross for at selskapet hadde belgiske aksjonærer. Skillet mellom primærregler og sekundærregler kan imidlertid ikke trekkes helt skarpt, og det har ingen direkte rettslig betydning. Det er likevel et nyttig redskap for å forstå reglene om statsansvar.

Sekundæerreglene om konsekvensene av folkerettsbrudd inneholder altså ikke noe krav om skyld. Imidlertid kan den enkelte primcrregelen som brytes sies å være enten «subjektiv» eller «objektiv». Disse begrepene kan brukes om flere ulike skiller. ILCs offisielle kommentarer nevner ett skille, nemlig mellom regler som krever en bestemt intensjon og regler som ikke stiller krav til intensjon. ${ }^{11}$ Et eksempel på det første er reglene om folkemord, som krever intensjon om å ødelegge en folkegruppe, mens et eksempel på det siste er brudd på diplomatisk immunitet. Et annet mulig skille går mellom regler som krever subjektiv skyld (som uaktsomhet) og regler som ikke krever dette. Regler som krever subjektiv skyld er imidlertid lite praktiske i folkeretten, ettersom det er vanskelig å bevise dette når man har å gjøre med en stat. ${ }^{12}$ Det man derimot finner i folkeretten, i tillegg til regler som krever en særskilt intensjon for å brytes, er forpliktelser som kun krever en innsats, kontra forpliktelser som krever et bestemt resultat. Et eksempel på en innsatsforpliktelse er VCDR Artikkel 22(3), som forplikter en vertsstat til å «take all appropriate steps» for å beskytte fremmede ambassader. Her er nok at staten gjør en tilstrekkelig innsats, uavhengig av om resultatet blir at ambassaden faktisk utsettes for et angrep. Dette kan kontrasteres med for eksempel VCDR Artikkel 22(1), som forplikter vertsstatens myndigheter til å ikke entre ambassadeområdet. Her er det ikke nok å gjøre sitt beste for å ikke entre området - det er kun resultatet som teller.

\section{Jus cogens og erga omnes}

«Jus cogens» og «erga omnes» er to konsepter som har noen likheter, men som ikke må forveksles. Det spesielle med jus cogens-regler er at de ikke kan fravikes, mens det spesielle med erga omnes-regler er at brudd på dem kan påberopes også av parter som ikke er berørt av bruddet. Begge konseptene regnes som særskilte former for folkerettslig sedvanerett. For jus cogens-regler er det noe omdiskutert om de er del av sedvaneretten eller ikke, men den enkleste konklusjonen er at de er det. Begrepet «erga omnes» kan også brukes om traktater der alle parter kan påberope seg ethvert brudd, og altså ikke bare sedvanerett. Alle jus cogens-regler vil i praksis være erga omnes. Derimot vil ikke alle erga omnes-regler nødvendigvis være jus cogens.

Eksempler på jus cogens-regler er, ifølge ICJ, forbudene mot folkemord, ${ }^{13}$ tortur $^{14}$ og bruk av væpnet makt. ${ }^{15}$ Eksempler på erga omnes-regler er forbudene mot folkemord, tortur, bruk av

\footnotetext{
${ }^{10}$ ICJ, Barcelona Traction, Light and Power Company, Limited, Judgment, I.C.J. Reports 1970, p. 3

${ }^{11}$ RSIWA med kommentarer Artikkel 2, avsnitt 3.

12 James Crawford, Brownlie’s Principles of Public International Law, Oxford 2012 s. 558.

${ }^{13}$ ICJ i Armed Activities on the Territory of the Congo (Democratic Republic of the Congo v. Uganda), Judgment, I.C.J. Reports 2005, p. 168, avsnitt 64.

${ }^{14}$ ICJ i Questions relating to the Obligation to Prosecute or Extradite (Belgium v. Senegal), Judgment,
} 
væpnet makt og rasediskriminering, ${ }^{16}$ folkenes selvbestemmelsesrett, ${ }^{17}$ og iallfall viktige deler av internasjonal humanitærrett. ${ }^{18}$

De rettslige konsekvensene av at en sedvanerettsregel er jus cogens, er kodifisert i VCLT Artikkel 53 og 64, og i RSIWA Artikkel 26. Disse bestemmelsene reflekterer folkerettslig sedvanerett. Ifølge VCLT Artikkel 53 vil en traktat der en bestemmelse er i strid med en eksisterende jus cogens-regel, bli ugyldig. Hele traktaten blir ugyldig, og ikke bare enkeltbestemmelser som måtte være i strid med en jus cogens-regel. Dersom to stater inngår en traktat der det blant annet fremgår at det er lov å begå folkemord, vil hele traktaten altså bli ugyldig.

Artikkel 64 regulerer situasjonen der en traktat blir inngått før en jus cogens-regel oppstår. Da vil jus cogens-regelen gjøre traktatbestemmelser som strider mot den ugyldige, men resten av traktaten blir ikke rammet.

RSIWA Artikkel 26 handler om samtykke. Forskjellen på å gi et samtykke og å inngå en traktat, er at et samtykke når som helst kan tilbakekalles, mens en traktat er bindende til den eventuelt opphører. Det er etter Artikkel 26 ikke tillatt å samtykke til brudd på en jus cogensregel. Stater kan ikke bli enige om at det er lovlig å begå folkemord eller tortur. Det er derimot tillatt å bruke væpnet makt på territoriet til en stat som samtykker til dette, selv om forbudet mot bruk av væpnet makt antas å være jus cogens. Dette er fordi adgangen til å bruke væpnet makt ved samtykke er del av selve forbudet, og RSIWA Artikkel 26 kommer derfor ikke til anvendelse. Maktbrukforbudet kan i denne forbindelse sies å være lex specialis, som ifølge RSIWA Artikkel 55 innebærer at RSIWAs regler fravikes.

De rettslige konsekvensene av at en sedvanerettsregel er erga omnes, finnes først og fremst i RSIWA Artikkel 48. Denne må ses i sammenheng med artikkel 42. Artikkel 42 angir en hovedregel om hvilke stater som kan påberope seg et folkerettsbrudd. I den forbindelse må man skille mellom bilaterale og multilaterale traktater, og mellom multilaterale traktater der staten har forpliktelser overfor hver enkelt annen stat («gjensidige») og overfor de andre statene som helhet («kollektive»). En multilateral traktat er kollektiv dersom alle traktatpartene anses å ha en rettslig interesse i ethvert brudd. Det motsatte kan kalles «gjensidige» multilaterale traktater. Et eksempel på en kollektiv traktat er Folkemordkonvensjonen. Et eksempel på en gjensidig traktat er VCDR.

Bilaterale og gjensidige traktater, og vanlig (ikke erga omnes) sedvanerett, reguleres av Artikkel 42(a). Ved brudd på slike regler fra én stat, er det den andre staten som kan påberope seg folkerettsbruddet. Artikkel 42(b) gjelder kollektive traktater og erga omnes. Her må en stat være særlig berørt («specially affected») for å kunne påberope seg et brudd (punkt i),

I.C.J. Reports 2012, p. 422, avsnitt 99; og (mindre uttrykkelig) i Ahmadou Sadio Diallo (Republic of Guinea $v$. Democratic Republic of the Congo), Merits, Judgment, I.C.J. Reports 2010, p. 639, avsnitt 87.

${ }^{15}$ ICJ i Military and Paramilitary Activities in and against Nicaragua (Nicaragua v. United States of America), Merits, Judgment. I.C.J. Reports 1986, p. 14. avsnitt 190.

${ }^{16}$ ICJ i Barcelona Traction, Light and Power Company, Limited, Judgment, I.C.J. Reports 1970, p. 3, avsnitt 34 bruker begrepet «aggression» om maktbrukforbudet, som kan ha et snevrere innhold enn maktbruk.

${ }^{17}$ ICJ i Legal Consequences cf the Construction of a Wall in the Occupied Palestinian Territory, Advisory Opinion, I.C.J. Reports 2004, p. 136, avsnitt 88 og 155-156, og East Timor (Portugal v. Australia), Judgment, I.C.J. Reports 1995, p. 90, avsnitt 29.

${ }^{18}$ ICJ i Legal Consequences cf the Construction of a Wall in the Occupied Palestinian Territory, Advisory Opinion, I.C.J. Reports 2004, p. 136, avsnitt 155. 
eller så må bruddet ha forrykket balansen mellom partene (punkt ii). En stat som omfattes av Artikkel 42 kalles «fornærmet» («injured»).

Artikkel 48 inneholder et tillegg til dette. Bestemmelsen gjelder for kollektive traktater og erga omnes sedvanerett. Den åpner for at en stat som ikke omfattes av Artikkel 42 også kan påberope seg brudd på slike bestemmelser.

Påberopelse av folkerettsbrudd har ulikt innhold under henholdsvis Artikkel 42 og Artikkel 48. Under Artikkel 42 omfatter det krav om opphør og ikke-gjentagelse etter Artikkel 30, og reparasjon etter Artikkel 31 og 34 til 39. Ved påberopelse under Artikkel 48, kan opphør og ikke-gjentagelse etter Artikkel 30 kreves, men reparasjon kan bare kreves til fordel for en fornærmet stat (jf. Artikkel 48.2). Det går også et skille mellom Artikkel 42 og 48 når det gjelder mottiltak, som beskrevet i punkt 4 nedenfor: En stat som er omfattet av Artikkel 42 kan iverksette mottiltak, men det er usikkert om en stat som bare omfattes av Artikkel 48 kan gjøre det.

Et praktisk eksempel på brudd på en erga omnes-regel, er Russlands bruk av væpnet makt mot Ukraina siden 2014. Norge er ikke en fornærmet stat i denne sammenheng, men hvis Russland for eksempel hadde akseptert ICJs jurisdiksjon, kunne Norge ha saksøkt Russland der, med krav om at russiske styrker trekkes ut av Ukraina og at annekteringen av Krim annulleres. Norge kunne ha krevd at Russland yter reparasjon til Ukraina, herunder kompensasjon for økonomisk skade. Hvis man mener at tredjestater kan iverksette mottiltak under Artikkel 54, kunne Norge også velge å iverksette mottiltak - altså å slutte å respektere visse folkerettslige forpliktelser - overfor Russland, som diskutert i punkt 4 nedenfor.

Påberopelse av folkerettsbruddet ville ikke være avhengig av samtykke fra Ukraina.

Skillet mellom Artikkel 42(a) på den siden og 42(b) og 48 på den andre, kan illustreres med en tabell:

\begin{tabular}{|c|c|c|c|}
\hline \multicolumn{2}{|c|}{ Regeltype } & $\begin{array}{c}\text { Relevante } \\
\text { bestemmelser }\end{array}$ \\
\hline \multirow{2}{*}{ Sedvanerett } & \multicolumn{2}{|c|}{ Vanlig } & Art 42.a \\
\cline { 2 - 4 } & \multicolumn{2}{|c|}{ Erga omnes } & Art 42.b og 48 \\
\hline \multirow{3}{*}{ Traktater } & \multicolumn{2}{|c|}{ Bilaterale } & Art 42.a \\
\cline { 2 - 4 } & \multirow{2}{*}{ Multilaterale } & Gjensidige & Art 42.a \\
\cline { 2 - 4 } & & Kollektive & Art 42.b og 48 \\
\hline
\end{tabular}

\section{Mottiltak fra tredjestater}

Mottiltak er tiltak som iverksettes mot et folkerettsbrudd, og som ville ha vært folkerettsstridige under normale forhold, men som blir lovlige fordi vilkårene for mottiltak er oppfylt. Mottiltak reguleres av folkerettslig sedvanerett, reflektert i ILCs artikler om statsansvar (Artikkel 22 og 49 til 54).

For eksempel har Russland brutt forbudet mot bruk av væpnet makt overfor Ukraina siden 2013, ved å annektere Krim og sende militære styrker og våpen til opprørere i Donbass. Tredjestater, som Norge, kan ønske å svare med mottiltak. Dette vil være lovlig, så lenge de generelle vilkårene for mottiltak oppfylles. For eksempel kunne russiske fly nektes å lande i 
Norge, i strid med luftfartsavtaler. Sanksjonene som så langt er iverksatt av Norge og øvrige stater mot Russland, er tilsynelatende ikke ment å være mottiltak, men derimot tiltak som uansett ikke er i strid med folkerettslige forpliktelser.

Ifølge ILCs Artikkel 49(1), er det den fornærmede staten («injured state») som kan iverksette mottiltak. Iverksetting av mottiltak er frivillig (for den fornærmede staten, men naturligvis ikke for den skyldige staten). Det er altså ikke en automatisk konsekvens av folkerettsbrudd. Hva som er en «injured state» defineres i Artikkel 42, jf. diskusjonen i punkt 3 ovenfor.

Spørsmålet i dette punktet er hvorvidt tredjestater, altså stater som ikke er «injured», også kan iverksette mottiltak. Dette besvares ikke uttrykkelig i ILCs artikler. Det nærmeste man kommer er Artikkel 54. Denne bestemmelsen sier bare at artiklene om mottiltak ikke er til hinder for eventuelle andre lovlige tiltak («lawful measures»). Spørsmålet blir da om mottiltak fra tredjestater er lovlig. Dette avhenger av hva folkerettslig sedvanerett sier. Ifølge ILCs egne kommentarer til Artikkel 54 er dette usikkert. ${ }^{19}$ ILC baserer sine artikler på undersøkelser av blant annet statspraksis og rettspraksis. Deres konklusjon når det gjelder mottiltak fra tredjestater er at praksis går i begge retninger. ${ }^{20}$ Noe praksis tilsier at det er tillatt, mens annen praksis tilsier at det er forbudt. ICJ har heller ikke tatt stilling til spørsmålet. Poenget med Artikkel 54 er nettopp å holde spørsmålet åpent, og ILC overlater spørsmålet til senere rettsutvikling. ${ }^{21}$ På eksamen kan en student simpelthen legge til grunn det ene eller det andre, etter å ha vist at man kjenner til denne bakgrunnen for Artikkel 54 .

Artikkel 54 henviser til Artikkel 48. Artikkel 54 snakker om lovlige tiltak iverksatt av stater «entitled under article 48, paragraph 1». Artikkel 48(1) handler om tredjestaters («any State other than an injured State») adgang til å påberope seg folkerettsbrudd, for eksempel ved å gå til sak for en domstol. Dette gjelder for «kollektive forpliktelser» (bokstav a), og for «obligation[s] [...] owed to the international community as a whole». Det siste er en henvisning til såkalte erga omnes-regler (jf. diskusjonen i punkt 3 ovenfor). Dersom man mener at tredjestater har lov til å iverksette mottiltak, gjelder dette kun for kollektive forpliktelser og erga omnes-regler. Hvis en tredjestat ønsker å iverksette mottiltak, må man vurdere om den regelen som er brutt er en kollektiv traktatforpliktelse eller erga omnes sedvanerett.

\section{Vilkårene for statsdannelse}

Statene er de sentrale aktørene i folkeretten. Derfor har det stor betydning hva som er (eller ikke er) en stat. Dette er et rettslig spørsmål, som reguleres av folkerettslig sedvanerett. Denne sedvaneretten er til en viss grad kodifisert i Montevideo-konvensjonen Artikkel 1, men denne er ratifisert av få stater.

En stat dannes når visse vilkår er oppfylt. Nøyaktig hvilke vilkår som stilles, og hva de inneholder, varierer noe mellom ulike kilder og tekster. Ifølge Montevideo-konvensjonen stilles det fire vilkår: Staten må ha en fast befolkning (bokstav a), definert territorium (bokstav b), «government» (bokstav c), og evne til å inngå relasjoner med andre stater (bokstav d).

\footnotetext{
${ }^{19}$ RSIWA med kommentarer Artikkel 54, avsnitt 6.

${ }^{20}$ RSIWA med kommentarer Artikkel 54, avsnitt 3-6.

${ }^{21}$ RSIWA med kommentarer Artikkel 54, avsnitt 7.
} 
De to første vilkårene, om befolkning og territorium, er de greieste. Det finnes praktiske nedre grenser for hvor liten en stat kan være, både i areal og innbyggertall. Spørsmålet om det også juridisk sett finnes nedre grenser har imidlertid ikke kommet på spissen. Av dagens stater er Vatikanstaten minst, både i areal og innbyggertall, med under 1000 innbyggere og et territorium på 0,44 kvadratkilometer. For øvrig behøver ikke statens grenser å være endelig fastlagt for at vilkåret om territorium skal være oppfylt (Albania slapp inn i Folkeforbundet som stat uten å ha fastlagte grenser).

De to siste vilkårene kan kalles «selvstyre». Man kan skille mellom «indre» og «ytre» selvstyre. Man kan si at «indre» selvstyre er reflektert i Montevideo-konvensjonen Artikkel 1 bokstav c, og at «ytre» selvstyre finnes i bokstav $\mathrm{d}$.

«Government» kan oversettes til norsk som «regjering» eller «myndighet». Staten må ha myndighet over det den påstår er sitt territorium og sin befolkning, herunder en tilstrekkelig grad av faktisk kontroll. Dette er det sentrale vilkåret for statsdannelse. Denne myndigheten må, naturlig nok, utøves av de personene eller organene som hevder å handle på vegne av staten. «Government» har altså en formell og en reell side: Det må finnes noen som formelt hevder å være en stat, og disse må reelt utøve tilstrekkelig faktisk kontroll. Kontrollen handler om å kunne kontrollere hva innbyggerne i staten kan gjøre på statens territorium, og hva utlendinger (herunder fremmede militære styrker) kan gjøre der. Et område der loven ikke blir håndhevet, vil ikke oppfylle «government»-vilkåret. Det vil heller ikke et område som har blitt okkupert av fremmede militære styrker.

Evnen til å inngå relasjoner med andre stater er et formelt vilkår. De som pretenderer å være statens myndigheter må inneha evnen til å representere staten utad. Det er for eksempel ikke tilfelle for delstater i føderale stater (som USA, Tyskland, Brasil, og så videre), der den føderale myndigheten normalt har denne kompetansen. Det er ikke et krav at denne evnen blir brukt i praksis. For eksempel var Rhodesia (som i dag heter Zimbabwe) en apartheidstat som ingen andre stater ønsket å ha relasjoner med. Dette var ikke til hinder for at Rhodesia kunne anses som stat (hvis man mener at de øvrige vilkårene var oppfylt). Et annet eksempel er Somaliland, som er etablert på territorium som andre stater anser å tilhøre Somalia.

Kravet om «ytre» selvstyre har, i tillegg til denne formelle siden, også en reell side: Staten må være reelt uavhengig av andre stater. Dette reflekteres ikke i Montevideokonvensjonen, men er sikker sedvanerett. Uavhengighetsvilkåret er ikke oppfylt dersom staten er avhengig av hjelp fra en annen stat for å beholde sitt reelle indre selvstyre. Et eksempel på en enhet som ikke oppfyller vilkåret, er Nord-Kypros (som er avhengig av tyrkiske militære styrker for å holde Kypriotiske myndigheter på avstand).

Vilkårene for statsdannelse kan illustreres som følger:

\begin{tabular}{|c|c|c|}
\hline Vilkår & Forklaring & $\begin{array}{c}\text { Reflektert } i \\
\text { Montevideo- } \\
\text { konvensjonen }\end{array}$ \\
\hline Befolkning & Intet minstekrav & Ja \\
\hline Territorium & Intet minstekrav & Ja \\
\hline Indre selvstyre $\quad$ Formelt & $\begin{array}{c}\text { Påstått } \\
\text { myndighet }\end{array}$ & Ja \\
\hline
\end{tabular}




\begin{tabular}{|c|c|c|c|}
\hline & Reelt & $\begin{array}{c}\text { Fysisk } \\
\text { maktmonopol }\end{array}$ & Ja \\
\hline \multirow{2}{*}{ Ytre selvstyre } & Formelt & $\begin{array}{c}\text { Evne til } \\
\text { relasjoner }\end{array}$ & Ja \\
\cline { 2 - 4 } & Reelt & Uavhengighet & Nei \\
\hline
\end{tabular}

Per i dag er så godt som alt territorium på jorden del av en stat. Det betyr at statsdannelse stort sett må skje på en eksisterende stats territorium. Det er ikke noe prinsipielt i veien for dette. Hvis en ny politisk enhet etablerer seg på en (del av) en stats territorium, og oppfyller vilkårene for statsdannelse i en viss periode, vil den bli en stat. Den gamle staten vil da miste dette territoriet. Slik statsdannelse kan skje med eller uten den eksisterende statens samtykke. Man kan også ha en mellomsituasjon, der en eksisterende staten ser seg nødt til å samtykke, grunnet langvarige væpnede konflikter og/eller politisk press. Eksempler på statsdannelse ved fredelig samtykke, er Montenegros løsrivelse fra Serbia i 2006, og oppløsningen av Tsjekkoslovakia (ved dannelsen av Tsjekkia og Slovakia) i 1993. Eksempler på mer motvillige samtykker, er Indonesias samtykke til Øst-Timors løsrivelse i 2002, og Sudans samtykke til Sør-Sudans løsrivelse i 2011. Et eksempel på (forsøk på) løsrivelse uten samtykke, er Kosovos uavhengighetserklæring (fra Serbia) i 2008. «Den islamske staten» i Midtøsten har også nylig erklært seg uavhengig uten samtykke fra de relevante eksisterende statene.

I noen tilfeller kan gruppen som forsøker å løsrive seg, ha en folkerettslig rett til dette. Dette kalles gjerne «remedial seccession». I slike tilfeller vil den eksisterende staten ha en plikt til å la løsrivelsen gå sin gang, uten å forhindre den med makt. Det er usikkert om en slik rett er del av gjeldende folkerett, og i så fall hva som er vilkårene for å ha en slik rett. Canadas høyesterett antok i en uttalelse om Quebec at en slik rett kan foreligge, dersom et folk blir utsatt for kolonisering, fremmed undertrykkelse, dominans eller utnytting, eller nektes politisk deltagelse. ${ }^{22}$ Hvis retten eksisterer, tilligger den ethvert folk. Den vil altså være del av folkenes selvbestemmelsesrett, som er folkerettslig sedvanerett. ${ }^{23}$

Stater kan velge å anerkjenne eller ikke å anerkjenne andre (påståtte) stater. Dette har imidlertid ingen betydning for om noe folkerettslig sett er en stat. En politisk enhet kan anerkjennes uten å bli en stat, og den kan være en stat uten å anerkjennes. Stater må derfor overholde folkeretten også overfor andre stater som de ikke anerkjenner. Anerkjennelse kan imidlertid anses som statspraksis, og gi uttrykk for opinio juris. Dette er de to elementene som danner folkerettslig sedvanerett. Selv om anerkjennelser ikke påvirker den rettslige stillingen til en enkelt (potensiell) stat, er de med på å forme de generelle vilkårene for statsdannelse. Det er nettopp disse vilkårene som må anvendes for å avgjøre om noe er en stat. På denne måten kan man altså si at det er en rettslige sammenheng mellom anerkjennelse og statsdannelse. Fore at opinio juris skal foreligge, må statenes praksis være foretatt i den tro at de handler i tråd med en rettsregel. Anerkjennelse er ofte en politisk handling, som ikke behøver å si noe om den aktuelle statens syn på folkeretten. Dette kan være et hinder for å bruke anerkjennelse som grunnlag for å si noe om de rettslige vilkårene for statsdannelse. For eksempel anerkjenner ikke Pakistan Armenia, selv om Armenia tilsynelatende oppfyller

\footnotetext{
22 Canadas høyesterett, Reference re Secession of Quebec (1998) 85, avsnitt 154.

${ }^{23}$ ICJ i Legal Consequences cf the Construction of a Wall in the Occupied Palestinian Territory, Advisory Opinion, I.C.J. Reports 2004, p. 136, avsnitt 88 og 155-156, og East Timor (Portugal v. Australia), Judgment, I.C.J. Reports 1995, p. 90, avsnitt 29.
} 
vilkårene for statsdannelse. Dette kan imidlertid forklares med at Pakistan handler politisk, på grunn av Armenias konflikt med Aserbajdsjan. Et annet eksempel er Palestina. Palestina oppfyller ikke kravet til reelt indre selvstyre, fordi det meste av Palestinas territorium er okkupert av Israel. Likevel er Palestina anerkjent av 135 av FNs 193 medlemsstater. Dette kan bety at man må ta en ny titt på vilkårene for statsdannelse, og si at disse må modifiseres slik at en stat kan dannes selv om dens territorium er okkupert. En alternativ fremgangsmåte er å anta at mange av anerkjennelsene av Palestina handler om politikk og ikke om juss.

Vilkårene for statsdannelse handler om når en stat dannes. Et annet spørsmål er hva som skal til for at en stat som allerede har blitt dannet skal opphøre. Det tillates at en stat ikke oppfyller vilkårene for statsdannelse i en periode uten at den opphører å være en stat. For eksempel har Somalia vært herjet av borgerkrig siden iallfall 1991, og har derfor manglet fullt reelt indre selvstyre, men Somalia regnes likevel som stat. Norge mistet reelt indre selvstyre under den tyske okkupasjonen i andre verdenskrig, men fortsatte som stat i 1945. De baltiske statene (Estland, Latvia og Litauen) mistet reelt indre selvstyre da de var okkupert av Sovjetunionen mellom 1940 og 1991. I 1991 valgte noen steder å anse dem som de samme statene som ble okkupert i 1940, mens andre valgte å anerkjenne dem som nye stater. Dette kan bety at stater kan overleve i så mye som 50 år selv uten å oppfylle alle vilkårene for statsdannelse.

\section{Sikkerhetsrådets materielle kompetanse er begrenset}

Sikkerhetsrådet er et av FNs organer, og dets virksomhet reguleres av FN-pakten kapittel V, VI og VII. I kraft av kapittel VII kan Sikkerhetsrådet treffe vedtak som er bindende for FNs medlemsstater. Denne kompetansen er vidtrekkende, men den er underlagt begrensninger.

I denne sammenhengen kan det være nyttig å skille mellom materiell, personell og prosessuell kompetanse. Materiell kompetanse handler om hva som kan vedtas, personell kompetanse handler om hvem som kan fatte vedtak det og hvem vedtaket kan rettes mot, mens prosessuell kompetanse handler om hvordan man må gå frem for å treffe et vedtak. Dette punktet handler om Sikkerhetsrådet materielle kompetanse, og målet er å vise at denne er begrenset, selv om det ikke finnes etablerte prosedyrer for å håndheve disse begrensningene.

Sikkerhetsrådets adgang til å treffe bindende vedtak er skapt, og dermed begrenset, av Artikkel 39-42. ${ }^{24}$ Artikkel 41 gir Sikkerhetsrådet adgang til å treffe ikke-militære tiltak, mens Artikkel 42 gjelder militære tiltak. Artikkel 40 handler om midlertidige tiltak. Artikkel 39 oppstiller tre alternative inngangsvilkår, ved å si at Sikkerhetsrådet bare kan handle etter Artikkel 41 og 42 (og 40) dersom det foreligger enten en trussel mot eller brudd på «freden» («the peace»), eller en aggresjonshandling. «Freden» viser her til «internasjonal fred», i motsetning til rent interne forhold i en stat. Artikkel 39 sier at Sikkerhetsrådet skal avgjøre («shall decide») hvorvidt det eksisterer en Artikkel 39-situasjon. Det er viktig å merke seg at dette er en prosessuell og personell, men ikke materiell, bestemmelse. Den sier hvem som skal ta avgjørelsen om hvorvidt det foreligger en Artikkel 39-situasjon, og at dette må gjøres

\footnotetext{
${ }^{24}$ ICJ sa i Admission of a State to the United Nations (Charter, Art. 4 ), Advisory Opinion: I.C.J. Reports 1948, p. 57, s. 64 at FNs organer er underlagt den frihet og de begrensninger som følger av FN-pakten. ICTY sa i ankeavgjørelsen om jurisdiction i Tadic (Prosecutor v. Dusko Tadic aka «Dule» (Decision on the Defence Motion for Interlocutory Appeal on Jurisdiction), 2. Oktober 1995, IT-94-1), avsnitt 28 at Sikkerhetsrådet er gitt en stor skjønnsfrihet, men at dets myndighet er underlagt rettslige begresninger, herunder i FN-pakten.
} 
for at Artikkel 40-42-tiltak skal kunne treffes. Det er altså Sikkerhetsrådet, og ingen andre, som skal gjøre dette. Det Artikkel 39 ikke sier, er at Sikkerhetsrådet materielt sett står fritt til å kalle hva som helst en trussel mot, eller et brudd på, freden eller en aggresjonshandling. Dette er materielle vilkår, som Sikkerhetsrådet må holde seg innenfor. Hvis ikke, vil et eventuelt vedtak etter Artikkel 40-42 være ugyldig. For eksempel er det ingen tvil om at Iraks invasjon av Kuwait i 1990 var et brudd på freden, og for så vidt også en aggresjonshandling. Sikkerhetsrådets vedtak, herunder 678 om bruk av væpnet makt, var altså innenfor Artikkel 39. Eksempler på noe som ikke truer internasjonal fred, er en alminnelig voldshandling, slik som ran eller mord, uten noen internasjonal dimensjon.

Ytterligere materielle vilkår for Sikkerhetsrådet kompetanse finnes i Artikkel 40, 41, og 42. Artikkel 42-vedtak må være nødvendige for å motarbeide situasjonen det reageres mot. Dessuten må fredelige tiltak anses, eller ha vist seg å være, utilstrekkelige.

I praksis er det ingen som har formell myndighet til å overprøve sikkerhetsrådets vedtak. Ingen domstol kan sette vedtakene til side med bindende virkning for Sikkerhetsrådet. Det er imidlertid mulig at ICJ kan forsøke å gjøre dette i en fremtidig sak. ${ }^{25}$ Stater kan hevde at et vedtak er ugyldig, og nekte å respektere det, ${ }^{26}$ men så lenge andre stater er uenige, vil de andre statene fortsette å handle i tråd med vedtaket.

Sikkerhetsrådet har brukt denne friheten til å subsumere en rekke situasjoner under begrepet «threat» i Artikkel 39. Dette inkluderer statskupp mot en demokratisk valgt regjering, ${ }^{27}$ angrep mot humanitære forsyninger i en borgerkrig, ${ }^{28}$ flyktningestrømmer til naboland, ${ }^{29}$ angrep på sivilbefolkningen i en borgerkrig, ${ }^{30}$ den nylige ebola-epidemien i Vest-Afrika ${ }^{31}$ og internasjonal terrorisme. ${ }^{32}$ Hvorvidt man kan mene at disse tingene omfattes av Artikkel 39, kommer an på hvordan man definerer trussel («threat») og fred («peace»). Hvor stor sannsynlighet for uroligheter må til før en situasjon blir en «trussel», og hvor mye potensiell uro skal til før man kan si at «freden» er truet? Dette er vanskelige tolkningsspørsmål, og det er plausibelt å hevde at Sikkerhetsrådet har holdt seg innenfor en rimelig tolkning av Artikkel 39. En annen sak er at Sikkerhetsrådets egne vedtak, kombinert med at FNs medlemmer stort sett godtar dem uten protest, kan anses som etterfølgende tolkningspraksis under VCLT Artikkel 31(3)(b), og dermed i seg selv være relevante for tolkningen av Artikkel 39.

\footnotetext{
${ }^{25}$ Spørsmålet ble unngått av ICJ i Lockerbie-sakene (Questions of Interpretation and Application of the 1971 Montreal Convention arisingfrom the Aerial Incident at Lockerbie (Libyan Arab Jamahiriya v. United Kingdom), Preliminary Objections, Judgment, I.C.J. Reports 1998, p. 9 og Questions of Interpretation and Application of the 1971 Montreal Convention arisingfrom the Aerial Incident at Lockerbie (Libyan Arab Jamahiriya v. United States of America), Preliminary Objections, Judgment, I.C.J. Reports 1998, p. 115, avsnitt 44).

${ }^{26}$ Antonios Tzanakopoulos, Disobeying the Security Council: Countermeasures against Wrongful Sanctions, Oxford 2011.

27 Sikkerhetsrådsresolusjon nr. 940 (1994).

28 Sikkerhetsrådsresolusjon nr. 794 (1992).

29 Sikkerhetsrådsresolusjon nr. 668 (1990).

30 Sikkerhetsrådsresolusjon nr. 1973 (2011).

31 Sikkerhetsrådsresolusjon nr. 2177 (2014).

32 Sikkerhetsrådsresolusjon nr. 1373 (2001).
} 
Dersom et organ skulle ha myndighet til å overprøve Sikkerhetsrådets vedtak, ville det nok også ha lagt inn en viss grad av skjønnsmargin. ${ }^{33}$ Et tilsvarende prinsipp anvendes når domstoler overprøver forvaltningsvedtak i norsk rett, og forvaltningen gis en grad av skjønnsfrihet i tolkningen og anvendelsen av skjønnsmessige begreper. ${ }^{34}$ EMD anvender også en «margin of appreciation», når den vurderer om EMK er overholdt. ${ }^{35}$

\section{Intervensjon, bruk av væpnet makt, og væpnet angrep}

Folkeretten inneholder forbud mot bruk av væpnet makt og intervensjon. Selvforsvar er et unntak fra maktforbudet, og grunnvilkåret for dette er at det foreligger et væpnet angrep. Målet med dette punktet er å forklare forskjellen mellom dem, og gi eksempler som viser hvor grensene mellom dem går og hvordan de overlapper.

Forbudet mot å bruke væpnet makt finnes i FN-pakten Artikkel 2(4) («use of force») og i folkerettslig sedvanerett. ${ }^{36}$ Kjernen i forbudet mot bruk av væpnet makt er krigshandlinger begått av én stat mot en annen. For eksempel fant ICJ at USA hadde brutt forbudet ved å bombe oljeplattformer i Iran, ${ }^{37}$ og ved å minelegge og angripe havner og oljeanlegg i Nicaragua, ${ }^{38}$ og at Rwanda brøt forbudet ved å sende militære styrker inn i Den demokratiske republikken Kongo ${ }^{39}$. Forbudet omfatter ifølge ICJ også tilfeller der en stat væpner og/eller trener opprørsstyrker som motarbeider en annen stat, som USA ble dømt for i Nicaraguasaken. ${ }^{40}$ USA hadde også finansiert opprørsstyrkene, men dette falt ifølge ICJ utenfor forbudet. $^{41}$

Væpnet makt kan brukes dersom et unntak fra forbudet kommer til anvendelse. Det finnes tre slike unntak: når staten som bruker væpnet makt har samtykke fra den andre staten, når den har autorisasjon fra FNs sikkerhetsråd (jf. FN-pakten artikkel 42), ${ }^{42}$ og når den har blitt utsatt for et «væpnet angrep» («armed attack», jf. FN-pakten Artikkel 51 og tilsvarende sedvanerett ${ }^{43}$ ) fra den andre staten. Unntaket for væpnet angrep reiser noen vanskelige tolkningsspørsmål. Ett spørsmål er hvorvidt en stat kan bruke væpnet makt for å forsvare seg

${ }^{33}$ ICJs rådgivende uttalelse Certain expenses of the United Nations (Article 17, paragraph 2 , of the Charter), Advisory Opinion of 20 July 1962: I.C.J. Reports 1962, p. 151, s. 168 oppstiller en presumsjon om at når FN handler for å oppfylle sine formål, er vedtaket lovlig. Domstolen sier også at FN-organer som utgangspunkt må avgjøre sin egen kompetanse.

34 For eksempel Hans Petter Graver, Alminnelig forvaltningsrett, 4. utgave Oslo 2015 s. 242-254.

${ }^{35}$ For eksempel EMDs dom 7. desember 1976 Handyside mot Storbritannia avsnitt 48.

${ }^{36}$ ICJ i Military and Paramilitary Activities in and against Nicaragua (Nicaragua v. United States of America), Merits, Judgment. I.C.J. Reports 1986, p. 14, avsnitt 188-192.

37 Oil Platforms (Islamic Republic of Iran v. United States of America), Judgment, I.C.J. Reports 2003, p. 161, avsnitt 125.

${ }^{38}$ Military and Paramilitary Activities in and against Nicaragua (Nicaragua v. United States of America), Merits, Judgment. I.C.J. Reports 1986, p. 14, avsnitt 292.

${ }^{39}$ Armed Activities on the Territory of the Congo (Democratic Republic of the Congo v. Uganda), Judgment, I.C.J. Reports 2005, p. 168, avsnitt 345.

${ }^{40}$ ICJ i Military and Paramilitary Activities in and against Nicaragua (Nicaragua v. United States of America), Merits, Judgment. I.C.J. Reports 1986, p. 14, avsnitt 227-228.

${ }^{41}$ ICJ i Military and Paramilitary Activities in and against Nicaragua (Nicaragua v. United States of America), Merits, Judgment. I.C.J. Reports 1986, p. 14, avsnitt 227-228.

${ }^{42}$ FN-pakten Artikkel 39-42 reflekterer antagelig ikke sedvanerett, noe som betyr at Sikkerhetsrådet bare kan autorisere maktbruk for FN-medlemmer.

${ }^{43}$ ICJ i Military and Paramilitary Activities in and against Nicaragua (Nicaragua v. United States of America), Merits, Judgment. I.C.J. Reports 1986, p. 14, avsnitt 194. 
mot et forventet angrep før det finner sted. Israel påberopte seg dette da israelske jagerfly bombet en atomreaktor i Irak i 1981. ICJ har holdt dette åpent. ${ }^{44}$ Et annet spørsmål er hvorvidt en stat som utsettes for angrep fra en ikke-statlig gruppe kan angripe staten(e) der gruppen holder til. USA og deres allierte påberopte seg dette da de angrep Afghanistan i 2001. ${ }^{45}$ Spørsmålet kan sies å være uavklart. Sammenlignet med «use of force», utgjør «armed attack» en høyere terskel. ${ }^{46}$ Bruk av væpnet makt må altså være av en viss intensitet og varighet for å kvalifisere som væpnet angrep og dermed gi rett til selvforsvar. Som nevnt ovenfor vil væpning og trening av opprørsstyrker normalt være bruk av væpnet makt, men det vil normalt ikke være over terskelen for væpnet angrep. ${ }^{47}$

Forbudet mot intervensjon finnes i folkerettslig sedvanerett. ${ }^{48}$ Det er i noen grad reflektert i FN-pakten Artikkel 2(7), men den bestemmelsen gjelder kun intervensjon fra FN, og fra ikke stater. Forbudet mot intervensjon handler særlig om tilfeller der en stat blander seg inn i en annen stats indre anliggender, og mer generelt fiendtlige handlinger fra en stat mot en annen. Som nevnt ovenfor vil finansiering av opprørere i en stat ikke være bruk av væpnet makt (og dermed heller ikke væpnet angrep). Det vil imidlertid være intervensjon. ${ }^{49}$ Andre eksempler er brudd på folkerettens jurisdiksjonsregler, vidtgående etterretningsarbeid i en annen stat, og overflyvning av militær- eller spionfly uten samtykke ${ }^{50}$. Dessuten vil bruk av væpnet makt også være intervensjon. ${ }^{51}$ Begge forbudene vil derfor være brutt ved ulovlig bruk av makt. Forbudene mot bruk av væpnet makt gjelder imidlertid også for intervensjonsforbudet, så en lovlig bruk av væpnet makt vil ikke bryte intervensjonsforbudet.

\begin{tabular}{|l|l|l|l|}
\hline & Væpnet angrep & $\begin{array}{l}\text { Væpnet } \\
\text { makt }\end{array}$ & $\begin{array}{l}\text { Intervensjo } \\
\text { n }\end{array}$ \\
\hline Angrep med militcre styrker & (Hvis over terskel) & Ja & Ja \\
\hline Minelegging av havner & (Hvis over terskel) & Ja & Ja \\
\hline Bombing av oljeanlegg & (Hvis over terskel) & Ja & Ja \\
\hline Vcepning og trening av opprørere & Nei & Ja & Ja \\
\hline Finansiering av opprørere & Nei & Nei & Ja \\
\hline
\end{tabular}

\footnotetext{
${ }^{44}$ Military and Paramilitary Activities in and against Nicaragua (Nicaragua v. United States of America), Merits, Judgment. I.C.J. Reports 1986, p. 14, avsnitt 194; Armed Activities on the Territory of the Congo (Democratic Republic of the Congo v. Uganda), Judgment, I.C.J. Reports 2005, p. 168, avsnitt 143.

${ }^{45}$ Dette har støtte i Sikkerhetsrådets resolusjon 1368 (2001), men motsies i noen grad av ICJ i Legal Consequences cf the Construction of a Wall in the Occupied Palestinian Territory, Advisory Opinion, I.C.J. Reports 2004, p. 136, avsnitt 139.

${ }^{46}$ ICJ i Military and Paramilitary Activities in and against Nicaragua (Nicaragua v. United States of America), Merits, Judgment. I.C.J. Reports 1986, p. 14, avsnitt $191 \mathrm{og}$ Oil Platforms (Islamic Republic of Iran v. United States of America), Judgment, I.C.J. Reports 2003, p. 161, avsnitt 51.

${ }^{47}$ ICJ i Military and Paramilitary Activities in and against Nicaragua (Nicaragua v. United States of America), Merits, Judgment. I.C.J. Reports 1986, p. 14, avsnitt 195.

${ }^{48}$ ICJ i Military and Paramilitary Activities in and against Nicaragua (Nicaragua v. United States of America), Merits, Judgment. I.C.J. Reports 1986, p. 14, avsnitt 202.

${ }^{49}$ ICJ i Military and Paramilitary Activities in and against Nicaragua (Nicaragua v. United States of America), Merits, Judgment. I.C.J. Reports 1986, p. 14, avsnitt 242.

${ }^{50}$ ICJ i Military and Paramilitary Activities in and against Nicaragua (Nicaragua v. United States of America), Merits, Judgment. I.C.J. Reports 1986, p. 14, avsnitt 251.

${ }^{51}$ ICJ i Military and Paramilitary Activities in and against Nicaragua (Nicaragua v. United States of America), Merits, Judgment. I.C.J. Reports 1986, p. 14, avsnitt 251.
} 


\begin{tabular}{|l|l|l|l|}
\hline Innblanding $\mathrm{i}$ indre anliggender & Nei & Nei & Ja \\
\hline
\end{tabular}

\section{Uskyldig gjennomfart til havn}

Havretten har regler om «uskyldig gjennomfart». Retten følger av UNCLOS Artikkel 17, og er nærmere utdypet i Artikkel 18 til 32. Den er også folkerettslig sedvanerett. Retten gjelder for skip som seiler under én stats flagg og som befinner seg i en annen stats territorialfarvann.

Territorialfarvannet reguleres av UNCLOS Artikkel 2-16. Ifølge Artikkel 3 strekker det seg 12 nautiske mil (22,2 kilometer) fra en stats kyst. Utenfor territorialfarvannet ligger økonomisk sone og tilstøtende sone (hvis kyststaten har opprettet dette), jf UNCLOS Artikkel 33(2) og 57. Disse sonene overlapper, altså er havområdet umiddelbart utenfor territorialfarvannet både tilstøtende sone og økonomisk sone. Innenfor territorialfarvannet ligger enten fastland eller indre farvann, jf. UNCLOS Artikkel 5-14. I indre farvann og på fastlandet har kyststaten full jurisdiksjon, jf. UNCLOS Artikkel 2. I økonomisk og tilstøtende sone har kyststaten kun den jurisdiksjonen som er positivt angitt i UNCLOS, jf. Artikkel 33(1) og 56.

Utgangspunktet i territorialfarvannet er at kyststaten har full jurisdiksjon. Den kan altså utøve lovgivende, utøvende, og dømmende makt i territorialfarvannet. Dette vil for eksempel bety at Stortinget kan vedta at en norsk lov skal gjelde i norsk territorialfarvann, at politiet kan arrestere mannskap på utenlandske skip som bryter reglene, og at mannskapet deretter kan stilles for retten ved norske domstoler.

Retten til uskyldig gjennomfart er et unntak fra utgangspunkt om full jurisdiksjon. Når et skip oppfyller vilkårene for uskyldig gjennomfart, kan kyststaten bare utøve slik jurisdiksjon som er uttrykkelig tillatt etter UNCLOS. Reguleringer som staten vedtar må ha et lovlig formål (Artikkel 21(1)). De må heller ikke være for inngripende (Artikkel 24(1)).

Ifølge Artikkel 18.1 gjelder uskyldig gjennomfart i to ulike situasjoner: når skipet seiler gjennom territorialfarvannet uten å entre kyststatens indre farvann eller havner, og når skipet seiler gjennom territorialfarvannet nettopp for å entre kyststatens indre farvann eller havner. Dette punktet handler om det siste tilfellet. Et skip kommer altså fra den tilstøtende sonen, seiler inn i territorialfarvannet, og setter kursen mot land. Siden kyststaten har full jurisdiksjon over fastland og indre farvann, står den fritt til å nekte ethvert skip å seile dit. Et mulig unntak fra dette kan være en sedvanerettslig rett til nødhavn, altså til å gå til havn dersom det ellers er fare for tap av menneskeliv.

Retten til uskyldig gjennomfart gir derimot ikke rett til å gå til havn. Hvis skipet likevel prøver å seile til land uten tillatelse fra kyststaten, vil dessuten gjennomfarten ikke lenger regnes som uskyldig. Kyststaten står da langt friere til å gripe inn mot skipet. At gjennomfart i slike tilfeller ikke er uskyldig, følger ikke av UNCLOS. Artikkel 19 lister opp noen vilkår for uskyldig gjennomfart, men nevner ikke uautoriserte forsøk på å seile til land. Slik må det imidlertid være, man kan ikke forlange at kyststaten må vente helt til et skip faktisk har kommet i land før den griper inn. Da kan det allerede være for sent, og smuglet gods eller personer kan ha unnsluppet. At gjennomfarten ikke lenger vil være uskyldig, antydes av UNCLOS Artikkel 25(2), som sier at kyststaten kan gripe inn mot et skip som oppfyller vilkårene for uskyldig gjennomfart, dersom dette gjøres for å håndheve vilkår som kyststaten har satt for å tillate skipet å gå til land. Når kyststaten kan gi en tillatelse med vilkår og 
deretter håndheve vilkårene, ville det være merkelig om den ikke kunne gjøre noe mot et skip som ikke har noen tillatelse overhodet. 